\title{
Cara BPOM Memastikan Keamanan Obat Tradisional di Masyarakat
}

\author{
Fathia Nabila Aulani \\ Program Studi Profesi Apoteker, Fakultas Farmasi, Universitas Padjadjaran, Sumedang, 45363 \\ email: fathianbl@gmail.com
}

\begin{abstract}
Abstrak :
Obat Tradisional (OT) adalah bahan atau ramuan bahan yang berupa bahan tumbuhan, bahan hewan, bahan mineral, sediaan sarian (galenik), atau campuran dari bahan tersebut yang secara turun temurun telah digunakan untuk pengobatan, dan dapat diterapkan sesuai dengan norma yang berlaku di masyarakat. Mutu obat tradisional dari segi keamanan, kualitas dan khasiat harus benar-benar dipastikan untuk mencapai maksud atau tujuan dari penggunaannya. Pemastian dan pengawasan mutu obat dilakukan mulai dari proses obat terebut diproduksi hingga pada pengawasan mutu post-marketing yang dilakukan setelah obat tersebut beredar di masyarakat. Di Badan POM, apoteker sangat berperan dalam mengevaluasi sediaan farmasi seperti produk Obat, Obat Tradisional, Suplemen Kesehatan, dan juga sediaan diluar itu seperti kosmetik dan pangan. Sedangkan pada pengawasan post market apoteker berperan dalam melakukan audit komprehensif dari Hulu-Hilir secara rutin dan insidentil, Pengujian sampel, Monitoring Efek Samping Obat (MESO), Monitoring Efek Samping Obat Tradisional (MESOT) untuk memastikan bahwa produk yang beredar aman bagi konsumen.
\end{abstract}

Keyword : BPOM, keamanan obat, efek samping, apoteker

\section{Outline}

- Pendahuluan

- Peranan Apoteker di Mengawasi OT di BPOM

- Kesimpulan

\section{Pendahuluan}

Mutu obat tradisional dari segi keamanan, kualitas dan khasiat harus benar-benar dipastikan untuk mencapai maksud atau tujuan dari penggunaannya. Pemastian dan pengawasan mutu obat dilakukan mulai dari proses obat terebut diproduksi hingga pada pengawasan mutu post-marketing yang dilakukan setelah obat tersebut beredar di masyarakat.

Maraknya isu OT yang mengandung Bahan Kimia Obat (BKO) cukup meresahkan masyarakat, oleh karena itu perlu dilakukannya upaya terhadap perlindungan konsumen. Untuk melindungi konsumen dari produk-produk yang berbahaya diperlukan suatu sistem pengawasan terhadap peredaran produk-produk di masyarakat, yang mampu mendeteksi, mencegah dan mengawasi produk obat dan makanan yang melibatkan Produsen, Pemerintah dan Masyarakat, Pemerintah Republik Indonesia membentuk suatu lembaga bernama Badan Pengawasan Obat dan Makanan (BPOM). 


\section{Peranan Apoteker di Mengawasi OT di BPOM}

Apoteker sebagai sumber daya manusia yang mendukung tugas dan fungsi BPOM dalam hal penyusunan kebijakan, pengawasan, manajemen standar kualitas, regulasi keamanan dan jaminan mutu, serta fungsi administrasi sehingga dapat melindungi masyarakat dari obat dan makanan yang beresiko terhadap kesehatan.

BPOM dalam melaksanakan tugasnya memerlukan tenaga penunjang, maka dibentuk suatu Unit Pelaksana Teknis (UPT) yang bersifat mandiri yang melaksanakan tugas teknis operasional dan penunjang tertentu dari organisasi induknya. Menurut Peraturan Kepala Badan POM No. 14 Tahun 2014 menetapkan organisasi dan tata kerja UPT di lingkungan Badan POM yang terdiri dari Balai Besar Pengawas Obat dan Makanan (BBPOM) dan Balai Pengawas Obat dan Makanan (Balai POM) .

Kegiatan Balai meliputi pemeriksaan dan pengujian mutu produk terapeutik, narkotika, obat tradisional, kosmetik dan produk komplemen (Teranokoko); pangan dan bahan berbahaya; pengujian mikrobiologi; pemeriksaan dan penyidikan; serta sertifikasi dan layanan informasi konsumen.

Ruang lingkup sampel yang diuji di Laboratorium Teranokoko sesuai dengan kriteria produk yang menjadi target sampling oleh Bidang Pemeriksaan dan Penyidikan. Berdasarkan dari tujuan pengujian, kriteria produk obat tradisional yang dilakukan sampling terbagi menjadi dua tipe sampel yaitu sampel surveilan dan compliance.

a. Surveilan:

Dilakukan untuk mendeteksi secara dini produk obat tradisional yang diduga mengandung BKO. Contoh obat tradisional yang disampling:

- OT dari produsen baru

- OT dengan klaim khasiat stamina/sehat pria

- OT dengan klaim khasiat/kegunaan pegal linu/encok/rematik/sakit pinggang/asam urat

- OT dengan klaim khasiat pelangsing/penurun kadar lemak/singset/diet, dsb.

b. Compliance:

Dilakukan untuk mengetahui apakah produk OT yang beredar konsisten memenuhi persyaratan keamanan, manfaat dan mutu seperti yang disetujui pada saat pendaftaran.

Contoh obat tradisional yang disampling:

- OT impor

- OT produksi dalam negri

- Sampling di sarana produksi

- OT yang produsennya telah memiliki sertifikat CPOTB 
Parameter pengujian terhadap sampel disesuaikan dengan bentuk sediaan, jenis dan tujuan dari pengujian.

Adapun parameter-parameter pengujiannya adalah sebagai berikut :

a. Identifikasi Bahan Kimia Obat (BKO).

b. Persyaratan farmasetika seperti waktu hancur, kadar air, kadar pengawet, kadar etanol dan metanol.

Obat tradisional dilarang mengandung:

a. etil alkohol lebih dari $1 \%$, kecuali dalam bentuk sediaan tingtur yang pemakaiannya dengan pengenceran;

b. bahan kimia obat yang merupakan hasil isolasi atau sintetik berkhasiat obat;

c. narkotika atau psikotropika; dan/atau

d. bahan lain yang berdasarkan pertimbangan kesehatan dan/atau berdasarkan penelitian membahayakan kesehatan

\section{Kesimpulan}

Di Badan POM, apoteker sangat berperan dalam mengevaluasi sediaan farmasi seperti produk Obat, Obat Tradisional, Suplemen Kesehatan, dan juga sediaan diluar itu seperti kosmetik dan pangan. Sedangkan pada pengawasan post market apoteker berperan dalam melakukan audit komprehensif dari Hulu-Hilir secara rutin dan insidentil, Pengujian sampel, Monitoring Efek Samping Obat (MESO), Monitoring Efek Samping Obat Tradisional (MESOT) untuk memastikan bahwa produk yang beredar aman bagi konsumen.

Selain itu, masyarakat saat ini dapat dengan mudah memastikan keamanan produk yang dikonsumsinya dengan cara cek nomor izin edar pada produk dengan menggunakan aplikasi Cek BPOM.

\section{Daftar Pustaka :}

PP No 80 tahun 2017 tentang Badan Pengawas Obat dan Makanan

PerKa BPOM No 14 Tahun 2014 Tentang Organisasi dan Tata Kerja Unit Pelaksana Teknis di Lingkungan Badan Pengawas Obat dan Makanan

Permenkes RI Nomor 006 Tahun 2012 Tentang Industri dan Usaha Obat Tradisional.

Permenkes RI Nomor 007 Tahun 2012 Tentang Registrasi Obat Tradisional. 